\title{
Exchange Rate Risk Management in Natural Rubber Industry: Implications for Multinational Corporations in China
}

\author{
Jun Zhou \\ Digital Business and Innovation, Tokyo International University, Kawagoe, Japan \\ Email: zhoujun120220@gmail.com
}

How to cite this paper: Zhou, J. (2021). Exchange Rate Risk Management in Natural Rubber Industry: Implications for Multinational Corporations in China. Open Journal of Social Sciences, 9, 663-672. https://doi.org/10.4236/jss.2021.99049

Received: September 3, 2021

Accepted: September 26, 2021

Published: September 29, 2021

\begin{abstract}
With the development of big data and information technology, the possibility of enhance the control of exchange rate risk in Chinese multinational corporations is increasing. A large of papers have already discussed exchange rate risk management, however the methodology used in accounting remain to be elucidated. This thesis focuses on China Hainan Rubber Industry Group Co. Ltd, analyzes problems of exchange rate management in its financial statements from 2015 to 2019, calculates the impact of exchange gains and losses with different accounting methods, and then discusses the policy implication. We set up a model to explain the details of exchange gains and loss, then subdivide (A) actual exchange gains and losses and (B) financial accounting exchange gains and losses to reflect the enterprise's business status, and verify the feasibility of this model for practical use. Finally, we provide new policy implications, such as suggestions for accounting entries with classified exchange gains and losses, strengthen enterprise communication management by using IT, and pay attention to the development trend of CNY's internationalization.
\end{abstract}

\section{Keywords}

Exchange Rate Risk Management, Exchange Gains and Losses, Communication Management, CNY Internationalization

\section{Introduction}

This research focuses on exchange rate risk management in Chinese multinational corporations in the era of big data. It has important implications for accounting, financial management, information management, amongst other 
fields. Additionally, this research discusses the policy implications for efficient exchange rate risk management across all Chinese multinational corporations.

The multinational companies in China are facing the problem of multi-currency calculation. A floating exchange rate policy can influence the net profitability of enterprises. "In 2015 and 2016, the total amount of exchange losses reached 18 billion yuan and 37.5 billion yuan respectively" Liu (2019).

Business management in the future will profit from the data information. Ke and Shi (2014) pointed that the era of the big data opened up new opportunities for exchange rate risk management for enterprises. How do we make better use of the information? How much can enterprises benefit from risk management? Is it possible to modify the existing accounting methods to improve exchange rate risk management? These are the research questions that we aim to address in this thesis. This research will focus specifically on the natural rubber industry in China. And results are expected to have strong policy implications for efficient exchange rate risk management across Chinese multinational corporations.

\section{Literature Review}

Zhang and Liu (2009) summarized the translation methods of foreign currency in financial statements. For monetary items, they proposed, "the profits and losses of foreign exchange rate" and "change in fair value profit and loss" be added to the income statement and then filled out separately. The authors analyzed the importance of foreign currency translation from a theoretical standpoint.

Butler et al. (2013) felt that exchange rate fluctuations should be taken into account when proposing cross-border investments. Butler tested the valued and mis-valued spot exchange rates and obtained different results of net present value. They mainly discussed foreign currency conversions in the investment field.

Cao (2015) thought the issue of foreign currency translation should be discussed in two ways-(A) business way, and (B) the accounting translation way. For the latter, the problem arose when accountants prepare the financial report. It was denominated in foreign currency at the end of the period and didn't have any connection with the business. Therefore, it is necessary to list the two kinds of foreign exchange differences separately. According to the framework of the US Financial Accounting Standard Board (FASB), the difference caused by report translation should not be included in the scope of profit. In International Accounting Standards Board's (IASB) conceptual framework, it is not clear whether the difference enters into other comprehensive income or not. Cao (2015) suggested that the difference caused by report translation should be included in the capital reserve of the balance sheet and shown separately. It also should be listed separately as other comprehensive income in the owner's equity statement. Cao provided the thought to deal with the foreign currency translation by the two ways, which we want to further discuss in this paper.

In order to indicate the specialty about the impact of exchange rates on 
companies' financial statements, previous researchers focused on different industries. Wei and Yao (2020) pointed out that, in the era of big data, financial accounting should be transferred to management accounting based on the study of Offshore Oil Enterprises. Lin (2019) constructed the financial accounting management system of the shipping company based on Enterprise Resource Planning (ERP). Zhu (2018) based on the accounting treatment of foreign currency translation of China National Petroleum Corporation (CNPC). Zhao (2018) studied the financial statements of Air China, China Eastern and China Southern, and analyzed how each company's net profit was affected by currency fluctuations.

Paligorova and Staskow (2014) said hedging with derivatives can reduce financial risk. But it works better for large, mature companies. Wang (2020) points out the ability of China's enterprises to control foreign exchange risk lags for other countries. Liu (2019) listed companies from 2008 to 2016, and show that the management team with overseas experience could effectively use operational hedging and financial hedging to mitigate the impact of exchange rate changes by smoothing corporate earnings and improving corporate governance. It was found to significantly reduce exchange rate risk in enterprises.

Ke and Shi (2014) introduced the development history of data in accounting, manual process, network process, and big data process, etc., they emphasized the role of big data in budgeting, and management accounting, included real-time report. They reported that there were challenges in security and personal privacy.

Zhu (2001) pointed that financial management needs to strengthen its role in conducting a business. Additionally, their investment in internet technology is restricted.

\section{Research Methodology and Data Resource}

This research is based on a case study of China Hainan Rubber Industry Group Co. Ltd. (Hainan Rubber). The main research data of this paper is "The official financial statement" of Hainan Rubber from 2015 to 2019, and "The official explanation about the financial statement in 2019" from the third-party auditor. The data can be downloaded from Juchao Information website ${ }^{1}$.

This project investigates the items involved in financial statements such as accounts receivable and accounts payable, advance payment, etc., obtain the data related on foreign currency transactions, and then calculates the impact of different exchange rates on financial statements in different conversion exchange rates and examines the effects of this risk in accounting methods.

This paper has referred to numerous documents related to financial management. An extensive review of literature on exchange rate management is provided to enhance an understanding of the theoretical framework.

${ }^{1}$ Juchao Information website (http://www.cninfo.com.cn/new/index). Juchao Information website is designated by the China Securities Regulatory Commission. It discloses the important information of listed companies in China. Investors can look up the data they wanted. 


\section{Theory}

According to the conversion method disclosed by Hainan Rubber in its Annual Financial Report, the foreign currency conversion for Hannan Rubber is like the below:

1) Income statement: Foreign currency transactions are converted into CNY at the spot exchange rate on the transaction date.

2) Balance sheet: On the balance sheet date, foreign currency monetary items should be converted at the spot exchange rate on the balance sheet date. For initial recognition of the spot exchange rate before the balance sheet date, the differences are recorded in the income statements.

\section{Main Results and Discussion}

\subsection{The Impact on Balance Sheet}

We focused on the US dollar business and then take the intervals from the end of 2015 to the end of 2019 as the study period. First of all, the year-end figure for 2015 is considered as the starting figure for 2016. The year-end figure for 2019 is the last observation for 2019. Then, the amount for a specific period = the last observation - the start value. Lastly, we try to calculate the difference between the value for two periods separately by two methods. And then we check the differentials for each of these two methods.

1) Method One-The differential is incurred with annual exchange rate adjustment. The exchange rate in account balance should be adjusted by the spot exchange rate on the balance sheet date at the end of the year, and then take the sum of the balance of each account with CNY as the data for financial report. Taking cash as an example, the balance of cash with the exchange rate adjustment is

$$
\text { CNY269,362,518.71 - CNY271,199,842.18 = -CNY1,837,323.47. }
$$

2) Method Two-The differential is incurred with annual non-exchange rate adjustment. Instead of conducting exchange adjustment on the balance sheet date of each year, the second method uses foreign currency balance to calculate directly. Details are:

(Foreign currency balance at last observation-Foreign currency balance at the start value) ${ }^{*}$ the exchange rate of foreign currency at last observation period.

With this method, we can get the amount when the exchange rate is not adjusted. Also taking cash as an example, the account balance without exchange rate conversion

$$
(U S D 38,611,639.39-\mathrm{USD} 41,764,174.29) * 6.9762=-\mathrm{CNY} 21,992,713.97 .
$$

Based on the two methods, we calculate the balance of Cash, Accounts Payable, and other items separately. Then obtain the owners' equity base on below equations.

$$
\text { Owners' equity }=\text { Assets }- \text { Liabilities }
$$

In our case, we simplify this equation as: 
Table 1. Indicates the difference between annual exchange rate adjustment and annual non-exchange rate adjustment.

\begin{tabular}{|c|c|c|c|c|}
\hline Items & Year & Balance of USD & Exchange Rate & Balance of CNY \\
\hline \multirow{5}{*}{ Cash } & 2019 & $38,611,639.39$ & 6.9762 & $269,362,518.71$ \\
\hline & 2018 & $26,112,984.30$ & 6.8632 & $179,218,633.85$ \\
\hline & 2017 & $15,786,279.12$ & 6.5342 & $103,150,705.02$ \\
\hline & 2016 & $11,720,978.21$ & 6.9370 & $81,308,425.84$ \\
\hline & 2015 & $41,764,174.29$ & 6.4936 & $271,199,842.18$ \\
\hline \multicolumn{2}{|c|}{$\begin{array}{l}\text { Period amount incurred with } \\
\text { annual exchange rate adjustment }\end{array}$} & \multicolumn{3}{|c|}{$-C N Y 1,837,323.47$} \\
\hline \multicolumn{2}{|c|}{$\begin{array}{l}\text { Period amount incurred with } \\
\text { annual non-exchange rate adjustment }\end{array}$} & \multicolumn{3}{|c|}{$-C N Y 21,992,713.97$} \\
\hline \multirow{5}{*}{ Accounts Receivable } & 2019 & $81,926,634.06$ & 6.9762 & $571,536,584.53$ \\
\hline & 2018 & $9,681,369.10$ & 6.8632 & $66,445,172.37$ \\
\hline & 2017 & $25,856,600.98$ & 6.5342 & $168,952,202.12$ \\
\hline & 2016 & $26,838,666.12$ & 6.9370 & $186,179,826.87$ \\
\hline & 2015 & $43,040,646.91$ & 6.4936 & $279,488,744.78$ \\
\hline \multicolumn{2}{|c|}{$\begin{array}{l}\text { Period amount incurred with } \\
\text { annual exchange rate adjustment }\end{array}$} & \multicolumn{3}{|c|}{$C N Y 292,047,839.75$} \\
\hline \multicolumn{2}{|c|}{$\begin{array}{l}\text { Period amount incurred with } \\
\text { annual non-exchange rate adjustment }\end{array}$} & \multicolumn{3}{|c|}{$C N Y 271,276,423.56$} \\
\hline Other & 2019 & $872,852.86$ & 6.9762 & $6,089,196.12$ \\
\hline Accounts Receivable & 2015 & $798,490.35$ & 6.4936 & $5,185,076.95$ \\
\hline \multicolumn{2}{|c|}{$\begin{array}{l}\text { Period amount incurred with } \\
\text { annual exchange rate adjustment }\end{array}$} & \multicolumn{3}{|c|}{$C N Y 904,119.17$} \\
\hline \multicolumn{2}{|c|}{$\begin{array}{l}\text { Period amount incurred with } \\
\text { annual non-exchange rate adjustment }\end{array}$} & \multicolumn{3}{|c|}{$C N Y 518,767.74$} \\
\hline Other & 2019 & $4,926,078.34$ & 6.9762 & $34,365,307.72$ \\
\hline Accounts Payment & 2015 & $2,797,232.01$ & 6.4936 & $18,164,105.78$ \\
\hline \multicolumn{2}{|c|}{$\begin{array}{l}\text { Period amount incurred with } \\
\text { annual exchange rate adjustment }\end{array}$} & \multicolumn{3}{|c|}{$C N Y 16,201,201.94$} \\
\hline \multicolumn{2}{|c|}{$\begin{array}{l}\text { Period amount incurred with } \\
\text { annual non-exchange rate adjustment }\end{array}$} & \multicolumn{3}{|c|}{$C N Y 14,851,257.77$} \\
\hline \multirow{2}{*}{ Accounts Payment } & 2019 & $47,051,150.70$ & 6.9762 & $328,238,237.51$ \\
\hline & 2015 & $2,289,339.27$ & 6.4936 & $14,866,053.49$ \\
\hline \multicolumn{2}{|c|}{$\begin{array}{l}\text { Period amount incurred with } \\
\text { annual exchange rate adjustment }\end{array}$} & \multicolumn{3}{|c|}{$C N Y 313,372,184.02$} \\
\hline \multicolumn{2}{|c|}{$\begin{array}{l}\text { Period amount incurred with } \\
\text { annual non-exchange rate adjustment }\end{array}$} & \multicolumn{3}{|c|}{$C N Y 312,267,348.90$} \\
\hline
\end{tabular}

Data source: Basic data from the Official Financial Statement of China Hainan Rubber Industry Group Co. Ltd from 2015-2019. 
Owners' equity $=$ Cash + Accounts Receivable + Other Accounts Receivable - Other Accounts Payment - Accounts Payment.

Then substituting the amounts from Table 1, we obtain:

- Method One:

Owners' equity $=-$ CNY1, 837,323.47 + CNY292, 047,839.75 + CNY904,119.17

- CNY16, 201,201.94-CNY313,372,184.02

$=-\mathrm{CNY} 38,458,750.51$

- Method Two:

Owners' equity $=-\mathrm{CNY} 21,992,713.97+\mathrm{CNY} 271,276,423.56+\mathrm{CNY} 518,767.74$

- CNY14,851,257.77-CNY312,267,348.90

$=-\mathrm{CNY} 77,316,129.34$

The difference is CNY 38,857,378.83. That means, due to the annual exchange rate adjustment, CNY 38,857,378.83 reflect in the owner's equity through accounting in financial expenses. Moreover, since it is included in the calculation of profits and losses of the enterprise, this will also serve as the basis for tax payment and profit distribution. But this is caused entirely by the accounting calculation method, and has no relationship with the enterprise's business. The impact is that the annual exchange rate adjustment may increase the risk of the enterprise.

\subsection{The Impact on Income Statement}

Foreign currency transactions in the income statement can result in exchange rate risk. According to the financial statement of Hainan Rubber, their foreign currency businesses were converted into CNY at the spot exchange rate on the business date. Therefore, the choice of business date is crucial. The chart below is based on the description of Hainan Rubber's main sales in its financial statement from 2016 to 2019.

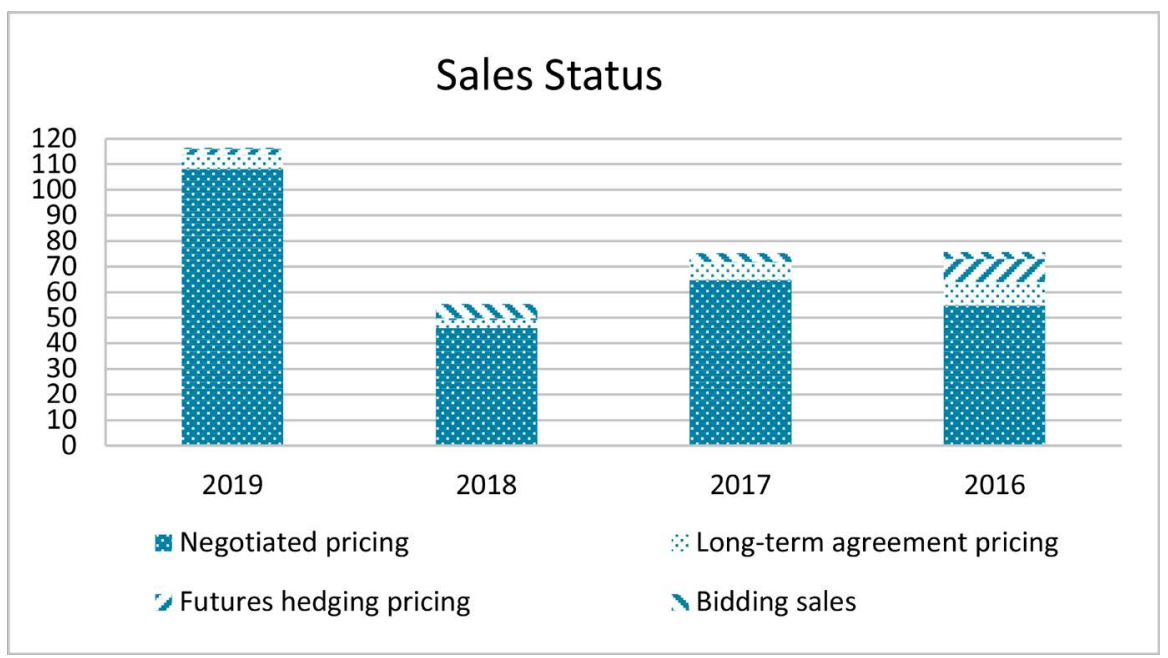

Figure 1. Sales Status from 2016 to 2019. Data source: Basic data from the Official Financial Statement of China Hainan Rubber Industry Group Co. Ltd from 2016-2019. 
The main sales business of Hainan rubber is composed of four sales modes. According to Figure 1, it can be seen that the main sales mode is negotiated pricing. That means the contract treaty shall be determined by the seller and the buyer through negotiation. This enables the sales staff to have some flexibility to choose the exchange rate that is favorable to the enterprise.

The exchange rate specified in the business contract will be the real exchange gains and loss of the enterprise. If the contract exchange rate is higher or lower than the bank exchange rate on the transaction day, then the enterprise will have gains and losses when they process the exchange settlement with the bank. It's a risk that requires special attention in the real business.

\section{Concluding Remarks}

The aforementioned discussion on the exchange gains and losses is confirmed in the enterprise's financial statements as per the adjustment rules of the exchange rate. Exchange gains and losses should be booked into the financial expenses and then added to the enterprise's profits and losses. It reflects the operating conditions of the enterprise. But, can this be improved? After all, the exchange rate is a factor beyond the enterprise's control. Therefore, we attempt to propose a hypothesis for exchange gains and losses in multiple categories.

According to the classification of exchange gains and losses of accounting standard for business enterprises of China, we combine with the above analysis of Hainan Rubber financial reports, and make the following assumption that the exchange gains and losses generated by the items listed in the balance sheet are related to the accounting methods. Enterprise's different accounting methods generate different exchange gains and losses, so the enterprise must identify the exact exchange gains and losses. At the same time, the exchange gains and losses reflected in the income statement are related to the contracts signed by the enterprise; that is, related to the daily transactions of the enterprise. The enterprise is expected to clarify the direction of the exchange rate management. For this purpose, this thesis presents the following model:

If exchange gains and losses can be subdivided into (A) actual exchange gains and losses and (B) financial accounting exchange gains and losses, that might better reflect the enterprise's business status. The model above could explain the relationship between (A) actual exchange gains and losses, and (B) financial accounting exchange gains and losses.

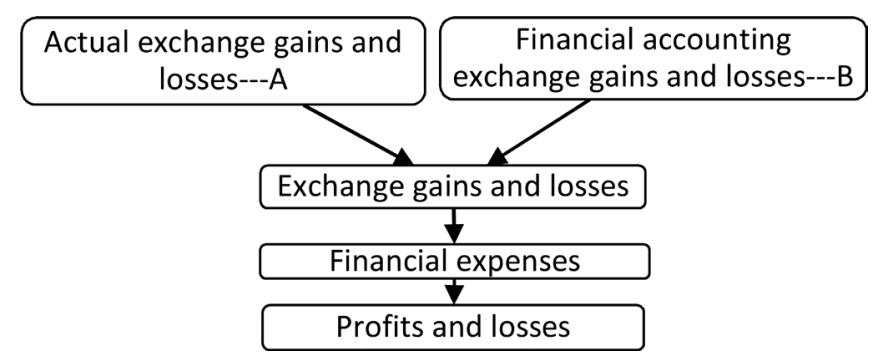

Figure 2. Diagram of exchange gains and losses. 
For (A), it is the real exchange gains and losses caused by the purchase or settlement of foreign currency for business transaction. The exchange rate gains and losses arising from the business contract are closely related to the actual business decisions of the enterprise. For (B), it is the booking exchange gains and losses generated from the currency conversion for the sake of consistency in statements. That is, in order to make financial estimates, the enterprise was forced to bear this part of the financial expenses or income, then had to add to the income statement as a measure of the enterprise's operating conditions. The exchange gains and losses generated from the balance sheet calculation belong to (B).

With this relationship in Figure 2, the current accounting standard of China does not need to change, but the exchange gains and losses of the enterprise will be clearer. And this relationship could help the management take rational decisions.

\section{Policy Implications}

\subsection{Suggestions for Accounting Entries}

Enterprises can distinguish exchange gains and losses under the financial expense account as (A) - actual exchange gains and losses, and (B) - financial accounting exchange gains and losses based on Figure 2. This method can split the transaction cost and the profit of the businesses more accurately. Method (A) is related to business transactions and Method $(B)$ is the accounting transaction cost. Based on this, Method (A) is the profit earned by the sales staff, and it can be assessed clearly. The figures will be more accurate and reflect the profit created by the sales staff for the enterprise. That will make the bonuses of sales staff more transparent. What's more, the accurate amount also inspires sales staff to pay more attention to exchange rate risk control. In the same way, for the distribution of shareholders' profits, the gains and losses caused by Method (B) should be considered as external factors. In this way, the actual exchange gains and losses of enterprises may be understood clearly. In addition, it's not complex to implement in practice. Because it can be implemented with the help of financial software automatically and then saves time and increases efficiency.

\subsection{Using Information Technology, We Can Strengthen the Communication Management to Conduct Businesses}

1) Pre-training to collect correct exchange rate information

With financial staff's pre-training, the salesman can take the real-time interest rate of the official bank as guidance when they negotiate on the terms and conditions of the contract.

2) Communication in time

a) With the development of mobile applications, improving communication amongst the staff will become easier. WeChat as an example, the number of active WeChat accounts by September 2019 was 1151 million, WeChat Data Re- 
port of 2019 (2020). It has the following benefits as a business communication tool:

- The communication mode is flexible. Multimedia channels are diversified.

- Audio messages and documents can be stored for a long time for review.

b) The importance of communication can reflect in the data update. The exchange rate is a factor of real-time change, so enterprises can take foreign exchange management as a start, and then gradually improve the timeliness of financial management. The benefits are:

- Make full use of the monetary funds. By accurately controlling the cashflow, financial staff can improve the utilization capital. Firstly, they can reasonably plan the loan amount to reduce the amount of loan interest. Secondly, they can use idle money to make short-term investments with low risk to earn profit.

- Make full use of the internal foreign currency capital resources of multinational enterprise groups to avoid foreign exchange losses.

- Make full use of banks' foreign exchange financial derivatives to lock the exchange rate risk in advance and reduce interest rate risks.

c) Communication in time has a greater dependence on IT. Besides ERP system, cloud disk may play an important role in data updates. The staff from different departments can update information to cloud disks in time if the network is secure.

\subsection{Promote CNY as the Settlement Currency}

If the CNY can be expanded and the application as an international transaction currency or as investment currency, the exchange risks of Chinese enterprises can be fundamentally reduced. It is universally acknowledged why the foreign exchange gains and losses bring risk to Chinese enterprises is that the currency of transactions and investments is in foreign currencies. At present, the internationalization of CNY has made remarkable achievements. "In 2018, CNY cross-border investment reached CNY2.66 trillion, and more than 70 central banks or monetary authorities included CNY in their foreign exchange reserves" Li et al. (2021). Multinational enterprises should capture the changes when determining the currency of the transaction.

In the financial market, China is accelerating the development of the financial derivatives market in the CNY-denominated currency. "In 2018, crude oil futures denominated and settled in CNY was officially traded on the Shanghai International Energy Trading Center” Zeng (2021). In 2019, natural rubber opened a CNY-denominated financial derivatives trading market at the Shanghai Stock Exchange (SSE). Hedging in the futures market is a common practice in bulk trading industry of agricultural products, they may become the new trading platform to increase the demand for CNY. Accountants in multinational enterprises should pour attention into this kind of information and constantly update their financial knowledge so as to increase profits and minimize risks for enterprises. 


\section{Conflicts of Interest}

The author declares no conflicts of interest regarding the publication of this paper.

\section{References}

Butler, K. C., O’Brien, T. J., \& Utete, G. (2013). A Fresh Look at Cross-Border Valuation and FX Hedging Decisions. Journal of Applied Finance, 2. https://ssrn.com/abstract $=2174448$

Cao, W. (2015). Discussion on Several Problems about the Foreign Currency Transaction Accounting Standards. Accounting Communication, 5-9.

Ke, M., \& Shi, Y. X. (2014). Big Data, Big Change: In the Financial Management. Open Journal of Accounting, 3, 77-82. http://dx.doi.org/10.4236/ojacct.2014.34009

Li, Y. N., Wen, J. D., \& Huang, M. H. (2021). The Process of CNY Internationalization: Theoretical Revision and Policy Adjustment. Sociological Abstracts, No. 1, 50-52.

Lin, P. (2019). Design and Implementation of Financial Accounting Information Management System of Shipping Companies Based on ERP [Special Issue]. Journal of Coastal Research, 94, 470-474. https://doi.org/10.2112/SI94-093.1

Liu, J. H. (2019). Whether the Overseas Experience of Senior Executives Reduces the Enterprise's Exchange Rate Risk. Journal of Zhongnan University of Economics and Law, 237.

Paligorova, T., \& Staskow, R. (2014). The Use of Financial Derivatives by Canadian Firms. Bank of Canada Review, 47-54.

Wang, Y. (2020). The Practical Application of Foreign Exchange Derivatives in the New Era for Small and Medium-sized Foreign Trade Enterprises. Foreign Economic and Trade Practice, 4, 69-72.

WeChat Data Report of 2019 (January 9, 2020). Chinese Internet Data Information Network. http://www.199it.com/archives/995970.html

Wei, R., \& Yao, S. (2020). Transformation from Financial Accounting to Management Accounting: A Study of the Offshore Oil Enterprises [Special Issue]. Journal of Coastal Research, 107, 9-12. https://doi.org/10.2112/JCR-SI107-003.1

Zeng, M. L. (2021). Research on the Development of CNY Valuation and Settlement of Bulk Commodities. Journal of Regional Financial Research, 2, 83-86.

Zhang, Z. L., \& Liu, K. (2009). A New Approach to the Translation of Foreign Currency Financial Statements in China. Finance and Accounting Monthly, 17, 50-51.

Zhao, L. S. (2018). The Influence of Foreign Exchange Risk Management on Corporate Profits-Based on Air Transport Industry Data. University of International Business and Economics.

Zhu, J. N. (2018). Accounting Treatment of Exchange Rate Risk Management in Multinational Enterprises-Based on the Research of CNPC. University of International Business and Economics.

Zhu, Y. W. (2001). Thinking of Establishing and Perfecting Internal Control. Accounting research, 24-65. 